\title{
가족성 Ring Chromosome 21 모자이크현상 1예 A Case of Familial Ring Chromosome 21 Mosaicism
}

\author{
강혜인 ${ }^{1}$ - 박성균 ${ }^{1}$ · 김도훈 ${ }^{1} \cdot$ 이원목 ${ }^{1}$ · 류남희 ${ }^{1}$ - 전동석 ${ }^{1}$ - 강석진 ${ }^{2}$ - 하정숙 ${ }^{1}$ \\ Hyein Kang, M.D. ${ }^{1}$, Sunggyun Park, M.D. ${ }^{1}$, Do-Hoon Kim, M.D. ${ }^{1}$, Wonmok Lee, M.D. ${ }^{1}$, Namhee Ryoo, M.D. ${ }^{1}$, \\ Dong-Seok Jeon, M.D. ${ }^{1}$, Seok Jin Kang, M.D. ${ }^{2}$, Jung Sook Ha, M.D. ${ }^{1}$ \\ 계명대학교 의과대학 진단검사의학교실1, 소아청소년과학교실2 \\ Departments of Laboratory Medicine ${ }^{1}$ and Pediatrics², Keimyung University School of Medicine, Daegu, Korea
}

Parent-to-child transmission of ring chromosome (RC) 21 with retained mosaicism has been reported very rarely. Here, we report a case of familial RC 21 mosaicism composed of several derivative clones resulted from mitotic instability of RC 21 . Mother had mos 46,XX,r(21)(pl3q22.3) [12]/46,XX[8], and her daughter had a more complex mosaicism, mos 47,XX, $+r(21)(p 13 q 22.3) m a t[4] / 45, X X,-21[3] / 46, X X, r(21)(p 13 q 22.3)$ mat[1]/47,XX, +dic r(21)[1]/46,XX[22].

Key Words: Ring chromosome, Mosaicism, Inheritance

\section{INTRODUCTION}

Ring chromosome (RC) is a circular DNA that results from breaks at the ends of both the chromosome arms followed by fusion of the broken ends [1]. During ring formation, genetic material might be lost or a complete ring with no deletion can be created by fusion of subtelomeric sequences or telomere-telomere fusion [2]. Most RCs are formed de novo. Only about 1\% of RCs have been found to be inherited from parents, and the most common RCs are RC 20, 21, 22, and 14 [3-5]. The reasons for the rare inheritance of RCs are thought to be the instability of the ring during meiosis and infertility of the carriers [3]. Among the inherited

Corresponding author: Jung Sook Ha, M.D., Ph.D.

(D) https://orcid.org/0000-0002-6475-4886

Department of Laboratory Medicine, Keimyung University School of

Medicine, 1035 Dalgubeol-daero, Dalseo-gu, Daegu 42601, Korea

Tel: +82-53-258-7938, Fax: +82-53-258-4228,

E-mail: ksksmom@dsmc.or.kr, ksksmom@naver.com

Received: March 30, 2020

Revision received: April 24, 2020

Accepted: May 6, 2020

This article is available from https://www.labmedonline.org (C) 2021, Laboratory Medicine Online

(a) This is an Open Access article distributed under the terms of the Creative Commons Attribution Non-Commercial License (https://creativecommons.org/licenses/by-nc/4.0/) which permits unrestricted non-commercial use, distribution, and reproduction in any medium, provided the original work is properly cited.
RC 21, cases of familial mosaicism in which mosaicism is retained between the generations have been found very rarely [6, 7].

Here, we report a rare case of familial RC 21 mosaicism where mother had mos 46,XX,r(21)(p13q22.3)[12]/46,XX[8]. Her daughter inherited RC 21 from her, but had a more complex mosaicism, mos 47,XX,+r(21)(p13q22.3)mat[4]/45,XX,-21[3]/46,XX,r(21) (p13q22.3)mat[1]/47,XX,+dic r(21)[1]/46,XX[22].

\section{CASE}

The proband, a 2-month-old girl, was the second-born child of unrelated parents. Her parents and 5-year-old sister had normal phenotype and intelligence. Her mother, aged 38, without any dysmorphism, had a history of spontaneous abortion (4 times) and a heart surgery due to atrial septal defect (ASD). To find out the reason for recurrent abortions, karyotyping was performed, which revealed mos 46,XX,r(21)(p13q22.3)[12]/46,XX[8] (Fig. 1). Microarray analysis using a CytoScan 750K array (Affymetrix, Santa Clara, CA, USA) detected no loss or gain of genetic material.

The proband was born at 38 weeks of gestation by caesarean section, with birth weight of 3,200 g. Karyotype by amniocentesis was normal at 16 weeks of gestation. However, after birth, low nasal bridge, mild facial dysmorphism, hypotonia, and a $2.3 \mathrm{~mm}$ ASD were detected. Conventional karyotyping revealed mos 
47,XX,+r(21)(p13q22.3)mat[4]/45,XX,-21[3]/46,XX,r(21)(p13q22.3) mat[1]/47,XX,+dic r(21)[1]/46,XX[22] (Fig. 2). Re-analysis of the same amniotic fluid sample revealed very low-level mosaicism of RC 21 (8 of the 100 metaphase cells examined).

Fluorescence in situ hybridization using RUNX1(21q22) probes showed three and one RUNX1 signals in 16\% and 5\% of the 200 metaphase cells, respectively. Microarray analysis for proband and karyotyping for proband's father and older sister were recommended through genetic counselling; however, those tests were refused.

\section{DISCUSSION}

Inheritance of $\mathrm{RC}$ is a very rare phenomenon. RC 22, RC 21, RC 20, and RC 14 are the most common among inherited RCs [3, 5]. This preference might be because of their relative stability during cell division and less phenotypic effect of these small chromosomes than the larger ones [3]. Particularly, high rate of mother-tochild RC transmission than father-to-child has been observed, although there are no sex differences in the prevalence of $\mathrm{RC}$ in general $[3,8]$. This difference is thought to be due to the deleterious effect of RC on spermatogenesis in male. However, no dis-
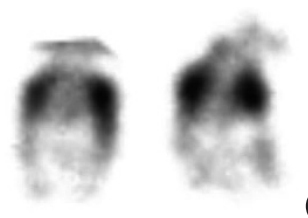

\section{A}
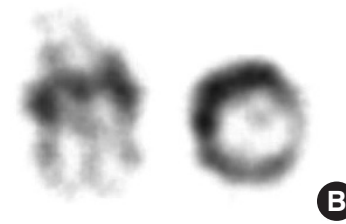

Fig. 1. Partial karyotype of mother showing normal 21 (A) and ring chromosome 21 (B). tinct effect on fertility has been reported in female [9].

In a review article, 9 out of 30 families with ring transmission showed that both the parent and the child were mosaic [3]. In our case of RC 21, both the mother and the daughter showed mosaicism. As the germline transmission of an RC should produce a non-mosaic karyotype, the reproduction of mosaicism in the offspring should be rare. Several hypotheses have been proposed to explain the co-occurrence of normal karyotype with $\mathrm{RC}$ in the offspring who has mosaic RC carrier parents: 1) early postzygotic loss of the ring and subsequent reduplication (monosomy rescue), 2) ring opening during early embryogenesis, and 3) postzygotic ring re-formation $[3,10,11]$. However, in addition to normal clone, our patient had several derivative clones, which could be explained by “dynamic mosaicism” [12, 13]. During cell division, if a ring replicates without sister chromatid exchange in the prophase, the separation of the ring results in the equal-sized rings. If sister chromatid exchange occurs through dicentric ring or interlocked ring formation, followed by asymmetric breakage, variable unbalanced products such as ring loss, dicentric RC, and duplication or additional RC could be produced in the daughter cells. This continuous production of aberrations in the daughter cells is referred as "dynamic mosaicism" [12-14].

Generally, inherited RC shows milder symptoms than sporadic case, which is more striking in the familial RC cases that rarely show major malformation [6]. However, formation of an additional RC 21 or duplication of Down syndrome critical region by dynamic mosaicism can lead to Down syndrome in RC 21 carriers $[15,16]$. In a report, the authors reviewed 26 cases of RC 21 carriers and found that 5 (21\%) of them had Down syndrome offspring, whose karyotype were either duplication of RC 21 or addi-

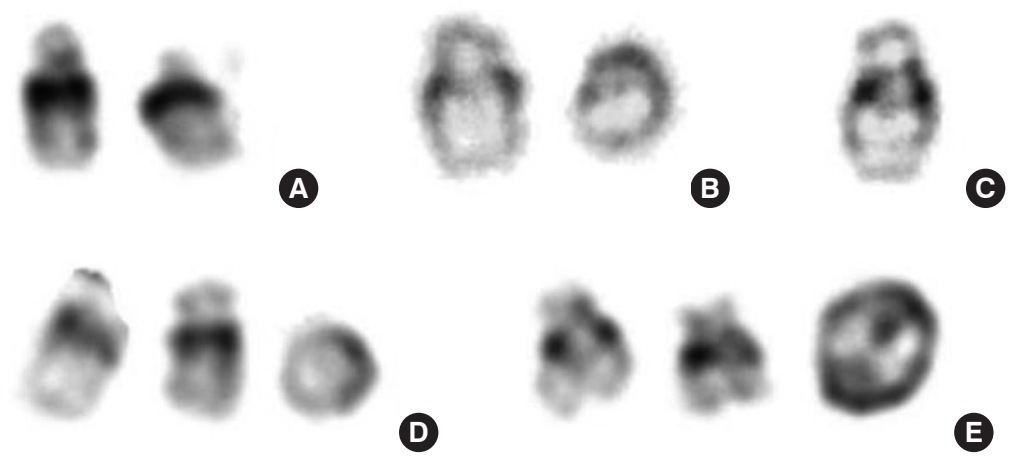

Fig. 2. Partial karyotype of daughter showing normal 21 (A), ring chromosome 21 (B), loss 21 (C), additional ring chromosome 21 (D), and additional dicentric ring chromosome 21 (E). 
tional RC 21 [6]. Our patient had additional RC 21 (16\% by fluorescence in situ hybridization) and dicentric RC 21 clones, and showed low nasal bridge, mild facial dysmorphism, and hypotonia, which were non-specific to be diagnosed as Down syndrome. The absence of symptoms or the presence of mild symptoms might be due to a low fraction of +21 clone or different proportion of mosaicism in different organs. Although she had ASD, we cannot be sure if ASD is related to RC 21 or trisomy 21, because her mother also had the same ASD. Therefore, long-term follow-up for proband is needed for the identification of more specific Down syndrome-related symptoms.

Here, we report a very rare case of a familial RC 21 mosaicism. When a new case of RC 21 is detected, detailed karyotyping for many metaphase cells should be performed to detect the mosaicism with variable RC 21 derivative clones. In addition, we recommend genetic counseling and family study, including parental and prenatal tests, because of the possibility of inheritance and recurrence of $\mathrm{RC}$.

\section{요 약}

부모에게서 자손으로 유전되는 ring chromosome (RC) 21 모자 이크현상은 매우 드물게 보고되어 있다. 저자들은 RC 21의 유사분 열 불안정성으로 인해 초래된 여러 개의 다른 클론으로 구성된 가 족성 RC 21 모자이크현상을 보고하고자 한다. 어머니의 핵형은 $\operatorname{mos} 46, \mathrm{XX}, \mathrm{r}(21)(\mathrm{p} 13 \mathrm{q} 22.3)[12] / 46, \mathrm{XX}[8]$ 이었으며, 딸의 핵형은 좀 더 복잡한 모자이크현상을 보여 $\operatorname{mos} 47, \mathrm{XX},+\mathrm{r}(21)(\mathrm{p} 13 \mathrm{q} 22.3)$ mat[4]/45,XX,-21[3]/46,XX,r(21)(p13q22.3)mat[1]/47,XX,+dic r(21) [1]/46,XX[22]이었다.

\section{Conflicts of Interest}

None declared.

\section{REFERENCES}

1. Sigurdardottir S, Goodman BK, Rutberg J, Thomas GH, Jabs EW, Geraghty MT. Clinical, cytogenetic, and fluorescence in situ hybridization findings in two cases of "complete ring" syndrome. Am J Med Genet 1999;87:384-90.
2. Le Caignec C, Boceno M, Jacquemont S, Nguyen The Tich S, Rival JM, David A. Inherited ring chromosome 8 without loss of subtelomeric sequences. Ann Genet 2004;47:289-96.

3. Kosztolányi G, Méhes K, Hook EB. Inherited ring chromosomes: an analysis of published cases. Hum Genet 1991;87:320-4.

4. Ikeuchi T, Yamamoto K, Qiao F, Hayakawa K, Migita T, Nishikawa Y. Ring chromosome 21 transmitted from mother to daughter: its stability in a lymphoblastoid cell line. Ann Genet 1990;33:32-5.

5. Arnedo N, Nogués C, Bosch M, Templado C. Mitotic and meiotic behaviour of a naturally transmitted ring $\mathrm{Y}$ chromosome: reproductive risk evaluation. Hum Reprod 2005;20:462-8.

6. Bertini V, Valetto A, Uccelli A, Tarantino E, Simi P. Ring chromosome 21 and reproductive pattern: a familial case and review of the literature. Fertil Steril 2008;90:2004.e1-5.

7. Howell RT, McDermott A, Gardner A, Dickinson V. Down's syndrome with a recombinant tandem duplication of chromosome 21 derived from a maternal ring. J Med Genet 1984;21:310-4.

8. MacDermot KD, Jack E, Cooke A, Turleau C, Lindenbaum RH, Pearson J, et al. Investigation of three patients with the "ring syndrome", including familial transmission of ring 5 , and estimation of reproductive risks. Hum Genet 1990;85:516-20.

9. Tulloch WS and Newsam JE. Studies on human meiotic chromosomes from testicular tissue. Lancet 1966;1:679-82.

10. Speevak MD, Smart C, Unwin L, Bell M, Farrell SA. Molecular characterization of an inherited ring (19) demonstrating ring opening. Am J Med Genet A 2003;121A:141-5.

11. Surace C, Berardinelli F, Masotti A, Roberti MC, Da Sacco L, D’Elia G, et al. Telomere shortening and telomere position effect in mild ring 17 syndrome. Epigenetics Chromatin 2014;7:1.

12. Pristyazhnyuk IE and Menzorov AG. Ring chromosomes: from formation to clinical potential. Protoplasma 2018;255:439-49.

13. Yip MY. Autosomal ring chromosomes in human genetic disorders. Transl Pediatr 2015;4:164-74.

14. McDermott A, Voyce MA, Romain D. Ring chromosome 4. J Med Genet 1977;14:228-32.

15. Matsubara T, Nakagome Y, Ogasawara N, Oka S, Yokochi T. Maternally transmitted extra ring (21) chromosome in a boy with Down's syndrome. Hum Genet 1982;60:78-9.

16. Miller K, Reimer A, Schulze B. Tandem duplication chromosome 21 in the offspring of a ring chromosome 21 carrier. Ann Genet 1987;30:180-2. 